\title{
Correspondence
}

\section{The just provision of health care} SIR,

Miss Telfer takes issue with three of my contentions concerning the proper basis for allocating health care resources (Fournal of medical ethics, 2, 188-9). First, she rejects my claim that, underlying her belief in the likelier adequacy of state provision than private provision, is an assumption that politicians are more charitable and provident than their electorate. This assumption is said to be absent because politicians, in providing such resources, are not giving away their own money and are making such provision through the instrument of law which is more reliable than private inclinations. But it is difficult to see how, in a democratic political system, politicians - whatever their motives - can persistently flout the wishes or inclinations of the bulk of the electorate. So the attribution of greater reliability to state provision must rest either upon the assumption that democratic politicians are, on this issue, invariably willing to commit electoral suicide, or upon the assumption that politicians would prefer to become undemocratic rather than jeopardize state health care programmes. Both of these assumptions attribute greater charity to politicians than to their electorate.

Second, she argues that althnugh state provision depends in principle upon the general retention of a sense of responsibility, in practice it undermines that sense and, thus, tends in the long term to be self destroying. It is not clear how this argument can be reconciled with Miss Telfer's previous point about the greater reliability of state provision. Nor is this the place to rehearse Kant's strictures about the common saying 'This may be true in theory but it does not apply in practice'. In any case, whether certain policies have a long-term tendency to erode the conditions for their own maintenance is an empirical (and not a philosophical) ques- tion, with the onus of proof surely lying on those who claim that an actually existing commitment will cease to exist.

Finally, Miss Telfer suggests that an equal distribution of wealth, coupled with unrestricted personal freedom to spend one's wealth, would require a greater degree of state control over private individuals - to establish that equality - than would a system whereby the state regulates and provides a wide range of services, and confiscates accordingly. Again, this seems to me to be an empirical rather than a philosophical contention, the truth of which entirely depends upon the kind of institutions and practices adopted for conferring an equal share of wealth upon each person. What does seem to be necessarily true, however, is that under such an arrangement the allocative pattern of goods and services would more closely conform to the detailed variety of individuals' respective preference orderings than would be the case under any other arrangement.

HILLEL STEINER

Department of Government University of Manchester

\section{Medical treatment of prisoners} SIR,

The medical treatment of prisoners is an important question for a humane society, and Dr Bowden's article $^{1}$ is welcome for drawing attention to it. Recently a prisoner was injured in a disturbance, suffering a fractured hand and leg and bruises and abrasions. Shortly afterwards he was certified medically fit to undergo punishment, and sentenced to a substantial period (9r days) of solitary confinement, during which his bed and bedding were removed from his cell during the day. Despite (or because of ?) the contentious circumstances, a request by the prisoner's father for an independent medical examination was refused.
This is admittedly an exception case, but it is in the exceptional cases that fundamental issues stand out most clearly. There must be manys prisoners in less dramatic circune stances who would say: 'I accep that the court ordered me to 6 deprived of my liberty; but by what right am I deprived also of a degree of choice of medical practitioner 9 MARTIN WRIGHY

Director, Howard League for Penal Reform

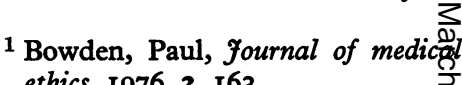
ethics, I976, 2, I63.

The need for more special hospitals

SIR,

The articles by Drs Rollin arget Norton $^{1,2}$ in your last issue ame timely because there has been in sufficient consideration of the Butler Report on Mentally Subnormâ] Offenders $^{3}$. It is true that the attempt to treat mentally abnormal offenders in mental hospitals follow ing the Mental Health Act of I9 has proved unsuccessful. However, the attempt was in keeping with the humane attitude to psychiatry whigh permeates most of the 1959 Act. The experience gained has been useful and the staffs of psychiatric hospitats are now qualified to comment on the problem. Very many psychiatrists are now familiar with many aspects of forensic psychiatry, and nursing staff in mental hospitals are expeff enced in the handling of patientis who come to them through the courts. The organization of mental hospitals represents a comprome between the need to treat patienfs with humanity and a lack of restriction and the need to protect societs from the violent patient. Since 1939 the emphasis has been more \& freedom and the patient's needs and less on restriction and the need fo protect society.

The Butler Report was publishgd because two mentally abnorn 